\title{
5. Sınıf Matematik Öğretmenlerinin Öğrenme Güçlüğüne Sahip Öğrencilerin Bulunduğu Sınıfta Oluşturmayı Amaçladığı Sosyomatematiksel Normlar
}

\section{Hava Öksüz1}

Nejla Gürefe ${ }^{2}$

\section{Type/Tür:}

Research/Araştırma

Received/Geliş Tarihi: May 25/

25 Mayis 2020

Accepted/Kabul Tarihi: October 3/ 3 Ekim 2020

Page numbers/Sayfa No: 601-626

Corresponding

Author/İletişimden Sorumlu

Yazar: havahazir@gmail.com

\section{$\checkmark$ iThenticate}

This paper was checked for plagiarism using iThenticate during the preview process and before publication. / Bu çalışma ön inceleme sürecinde ve yayımlanmadan önce iThenticate yazılımı ile taranmıştır.

Copyright (c) 2017 by Cumhuriyet University, Faculty of Education. All rights reserved.

\section{Öz}

Bu çalışmada kaynaştırma öğrencilerinden öğrenme güçlüğüne sahip öğrencilerin yer aldığı bir sinıfta matematik öğretmeninin sınıf içerisinde oluşturmayı amaçladığı sosyomatematiksel normları ortaya çıkarmak amaçlanmıştır. Çalışma durum çalışması niteliğindedir. Çalışmanın katılımcılarını Türkiye'nin batısındaki bir ilin ilçesine ait devlet okullarında eğitim veren ve sınıflarında birer tane öğrenme güçlügüune sahip öğrencinin bulunduğu üç matematik öğretmeni oluşturmuştur. Gözlem ve doküman yoluyla toplanan çalışmanın verileri içerik analizi kullanılarak analiz edilmiştir. Çalışmada öğretmenler tarafından matematiksel anlamda farklı çözümler gösterme, gerekçelendirmeden matematiksel açıklamayı kabul etme, sınıfta ortaya atılan matematiksel muhakemeleri gerekli sorgulamalarla masaya yatırıp tartışarak bir uzlaşmaya varma, kabul edilebilir matematiksel açıklama ve gerekçeler ortaya koyma, verilen hatalı çözümlerden faydalanarak doğru çözümler yapma, basit kolay ve etkili çözümler sergileme, rehberlik ederek, doğruyu buldurma, hatalı gösterimden faydalanarak genelleme yapma, bir öğrencinin çözümünü yeniden açıklama ve çözümleme, matematiksel doğruluğu kabul edilen çözümlerin yaptırılması şeklindeki normların oluşturulmaya çalışıldığı tespit edilmiştir. Çalışmanın bulgularından kaynaştırma öğretmenlerinin sınıflarında işe koştuğu sosyomatematiksel normların genel olarak öğrencinin anlamlı öğrenmesine olumlu katkı sağlayacak nitelikte olduğu fakat bunun yanı sıra süreçten ziyade sadece sonucu önemseyecek nitelikte öğrencinin gelişimine çok da katkısı olmayacak şekilde normların da oluşturulmak istendiği belirlenmiştir. Bulgular ışığında öğretmenlere öğrencilerin bir sorunun cevabından ziyade çözüm sürecine odaklanabilmelerini ve öğrencilerin daha özgür ve aktif olmalarını sağlayan sosyomatematiksel normları sınıflarında daha fazla işe koşması önerilebilir.

Anahtar Kelimeler: Sosyomatematiksel normlar, kesir, kaynaştırma matematik öğretmeni, öğrenme güçlüğüne sahip öğrenci, ortaokul.

Suggested APA Citation/Önerilen APA Atıf Biçimi:

Öksüz, H., \& Gürefe, N. (2021). 5. Sinıf matematik öğretmenlerinin öğrenme güçlüğüne sahip öğrencilerin bulunduğu sinıfta oluşturmayı amaçladığı sosyomatematiksel normlar. Cumhuriyet International Journal of Education, 10(2), 601-626. http:/ / dx.doi.org/10.30703/cije.742571

\footnotetext{
${ }^{1}$ Lisansüstü öğrenci, Uşak Üniversitesi, Uşak/Türkiye e-mail: havahazir@gmail.com ORCID ID: orcid.org/0000-0003-2201-4027

2 Doçent, Uşak Üniversitesi, Uşsak/Türkiye

e-mail: nejlacalik@gmail.com ORCID ID: orcid.org/0000-0002-0705-0890
}

Bu çalışma, ilk yazarın ikinci yazarın danışmanlığında yürütülen yüksek lisans tezinin bir parçası niteliğindedir. 


\title{
Sociomathematical Norms Aimed to be Created by 5. Grade Mathematics Teachers Having Learning Disabilities Students in Their Class
}

\begin{abstract}
In this study, it is aimed to reveal the socio-mathematical norms which the mathematics teachers aim to establish in a classroom where learning disabilities students from the mainstream students were included. The study is a case study. The participants of the study consisted of three mathematics teachers who had students with one learning disability in their classrooms. The data of the study collected through observation and document were analyzed using content analysis. In the study, it was determined that the teachers used the sociomathematical norms such as the showing different solutions, accepting mathematical explanation without justification, making the right solutions by making use of the wrong solutions given, presenting simple easy and effective solutions. The sociomathematical norms which the mathematics teachers aim to establish in their classrooms contribute positively to the meaningful learning of the student in general, but also the norms were used in a way that did not contribute much to the development of the student, who will not only care about the result, but also the process. In the light of the findings, teachers may be advised to use the sociomathematical norms more in their classrooms, which allows students to focus on the solution process rather than the answer to a question.
\end{abstract}

Keywords: Sociomathematical Norms, Fraction, Inclusive Mathematics Teacher, Learning Disabilities Student, Middle School.

\section{Giriş}

Vygotsky'e göre bilgi sosyo-kültürel ortamlarda anlamlandırılır ve yorumlanır. Nitekim son yıllarda yapılan çalışmalar (Cobb, Gravemeijer, Yackel, McClain ve Whitenack, 1997; Cobb ve Baursfeld, 1995) matematik bilme ve öğrenmenin sosyal ve kültürel bir süreç olduğu göstermiştir. Bu bağlamda Lopez ve Allal (2007)'e göre öğrenmeye, öğrencilerin sınıf içi kural, inanç, uygulama ve ürünlerinin bütünü katk1 sağlamakta ve bütün bunlar ancak sınıf üyeleri tarafından sahiplenildiği zaman gerçekleşmektedir. Bu anlamda bilginin, öğretmen ve öğrenciler arasındaki etkileşimle ve gerçekleştirilen etkinliklerle yapılandırıldığı söylenebilir. $\mathrm{Bu}$ etkileşimler öğrencilerin kendi matematiksel anlamlarını oluşturmalarını kolaylaştıracak şekilde öğrenme ortamını etkileme yeteneğine sahiptir. Bu bağlamda matematiğin sosyal yönüne vurgu yapan kuramlar matematik yapmanın bireysel bir aktiviteden daha çok sosyal bir aktivite olduğunu savunurlar (Herschkovitz ve Schwarz, 1999). Bu bilim adamları matematik öğrenimini analiz ederken sınıf mikrokültürü gibi bazı kavramlardan yararlanmışlardır (Cobb, 1999).

Öğrenme ve öğretme sürecinde, sınıf üyelerinin (öğretmen ve öğrenciler) sahip olduğu bilişsel yapılar ve sınıf üyelerinin karşılıklı etkileşim sonucunda ortaya çıkan ortak davranışlar sınıf mikrokültürünü oluşturur (Yackel ve Cobb, 1996). Sınıf mikrokültürünün bir parçası olarak Cobb, vd. (1992) ve Yackel ve Cobb (1996) öğretmenler ve öğrenciler arasında ortaya çıkan karşılıklı beklenti, kural ve davranışları yöneten ve yazılı olmayan ortak anlayışların ve sınıf içi kuralların tümünü ifade etmek için norm kelimesini kullanmışlardır. Normlar, sınıf içerisinde öğretmenlerin sözel olarak (Yackel ve Cobb, 1996) veya beden dili (Özmantar, vd., 2009) kullanarak oluşturdukları veya oluşumuna katkı sağladıkları yazılı olmyan sınıf içi kurallar veya ortak anlayışlardır (Boyunduruk, 2014). Van Zoest, Stockero ve Taylor (2012) ise sınıf içi normları, sınıf içerisindeki öğrenmeyi etkileyen 
davranışların düzenli bir örüntü şeklinde devam etmesi olarak adlandırmıştır. Buradan normların, öğretmenler ve öğrenciler arasındaki bir durum karşısında etkileşimi yöneten, yazılı olmayan fakat her bir birey tarafından kabul edilen ve tekrar gerektiren kurallar bütünü olduğu söylenebilir. Sınıf içi normlar öğrenciler ve öğretmenlerle birlikte oluşturulur. Öğrenciler bu oluşturma sürecine aktif olarak katılarak aynı zamanda kendi düşüncelerini de geliştirirler (Cobb ve Bauersfeld, 1995). Sosyal açıdan zengin ve güçlü olan sınıf ortamlarında öğrenciler her türlü problemi sorgulama ve muhakeme yoluyla çözerler (Akyüz, 2014). Özellikle sorgulama ve muhakemenin öne çıktığı bu sınıflardaki söylemler ile öğrenmeye yön veren iletişim, birinin diğerine üstünlüğü olmaksızın hem bireysel anlam oluşturma hem de sınıftaki tüm bireylere hitap eden ortak bir sosyal anlam oluşturma süreciyle etkileşime vurgu yapar (Yackel, 2001).

Cobb ve arkadaşları sosyal normların öğrencilerin gelişimine ve öğretmenin rolüne odaklanan matematik sınıfları için gerekli olduğunu savunmuşlardır (Şay, 2014). Sosyal normlarda yer alan açılamalarda bulunma, akranlarının çözüm yönlerini anlama ve gerekçelendirmede bulunma gibi normlar soyomatematiksel norm kavramının oluşmasını sağlamıştır. Sınıf mikrokültürü içerisinde öğrencinin matematikte neyi öğrenmeyi hedefe aldığı, hangi matematiksel açıklamaları doğru kabul ettiği ve matematik yapmayı nasıl anlamlandırdığı sosyo-matematiksel normlar içerisinde ele alınmaktadır (Cobb, 2000). Sosyo-matematiksel normlar sosyal normlar ile yakın ilişkiye sahip olup (Yackel, Rasmussen ve King, 2000) bir matematik sınıfındaki öğretme ve öğrenme etkinliklerinin kalitesini belirlemekte ve ayrıca öğrencilerin matematik etkinliklerini yönlendirmekte ve onları öğrenmeye teşvik etmektedir (Kang ve Kim, 2016). Cobb ve Yackel (1996) çalışmasında sosyomatematiksel normları öğrencilerin matematiksel faaliyetlerine özgü tüm sınıf tartışmalarının normatif yönleri olarak ele almışlardır.

Lampert (1990)'a göre, öğretmenin rolü öğrencilerle matematiksel tartışmalarda bulunmak ve sınıf içi söylemi düzenlemektir. Bunu başarmak için öğretmenin çözüme ilişkin cevap söyleme veya kuraldan daha fazlasını bilmesi gerekir. Öğretmen neyin kabul edilebilir olduğunu gösterir ve böylece sinıfında kurmak istediği sosyomatematiksel normları oluşturur. Öğretmen, öğrencilerin öğrenmelerinin daha iyi bir sistem içerisinde yapılandırılmasını sağlayan en önemli unsurlardan biridir. Dolayısıyla sınıf ortamında öğrencilerin vermiş olduğu cevaplar üzerine öğretmenlerin kullanmış olduğu jest ve mimikler (Özmantar vd., 2009) de dahil olmak üzere vermiş oldukları tüm tepkilerin (Yackel ve Cobb, 1996) öğrenciler için önemli olduğu söylenebilir.

Çağdaş eğitim anlayışına göre öğrenme sürecinde öğrenciye yardım ve rehberlik edilmesi öğretmenin görevleri arasındadır. Öğretmenlerin öğrencilere kazandırmaları gereken okuma, yazma, temel aritmetik işlemler ve problem çözme gibi bazı temel akademik beceriler vardır (Özkubat ve Özmen, 2018). MEB (2018) bu becerilerin eşit bir şekilde tüm öğrencilere kazandırılmasını hedefler. Nitekim bu öğrenciler içerisinde öğrenme güçlüğüne sahip öğrenciler de yer almaktadır. Özel öğrenme güçlüğü çeken öğrenciler 1940 yılı öncesinde bir çocuğun zihinsel yetersizlik göstermesi, duygusal bozukluklar göstermesi veya sosyokültürel yoksunluğuna sahip olması öğrenme güçlüğüne sahip olduğunu göstermekteydi (Akyol, 1997). Fakat daha sonraki yapılan çalışmalarda bu çocukların sorununun 
sebebinin tam belirli olmadığı ve öğrenme güçlüğünün beklenmedik, tipik olmayan öğrenme başarısızlığ1 (Fusch, Mock, Morgan ve Young, 2003) şeklinde tanımlandığ1 görülmüştür. Swanson ve Jerman (2006) de öğrenme güçlüğü çeken öğrencilerle yapılan çalışmaları incelediklerinde bu tür öğrencilerin normal gelişim gösteren akranlarına göre daha düşük bilişsel düzeye sahip olduklarını bulmuşlardır. Bu farklılıklar göz önünde bulundurulduğunda sınıf ortamının özel gereksinimi olan veya olmayan tüm bireyleri kapsayacak şekilde düzenlenmesi öğretmenin tutumu ile yakından ilişkilidir (Sart, Ala, Yazlık ve Yılmaz, 2004). Bu sebepten dolayı diğer ülkelerde olduğu gibi özel gereksinimi olan çocukların eğitimlerini akranlarıyla aynı okulda ve sınıfta sürdürmesi ilkesi benimsenmiş (Sucuoğlu ve Kargin, 2008) ve bu sınıflar kaynaştırma sınıfı olarak nitelendirilmiştir. Bu çalışma ile kaynaştırma sınıfında öğrenme güçlüğüne sahip öğrencilerin bulunduğu matematik öğretmenlerinin sınıf ortamında oluşturmaya çalıştıkları sosyomatematiksel normlar incelenmek istenmiştir. Shin ve Bryant (2015) öğrenme güçlügüüne sahip öğrencilerin matematikteki durumlarını incelediği araştırmalar sonucundaki değerlendirmesinde bu öğrencilerin "hesaplama yapma, problem çözme, matematik stratejilerini kullanma ve sayı sayma" becerilerinin akranlarına göre daha düşük olduğunu belirtmiştir. Nitekim bu çalışmada da sayılar ve işlemler konusundaki normlar incelenmiştir.

Alan yazın incelendiğinde sosyal ve sosyo-matematiksel normları belirlemek amacıyla birçok çalışmanın yapıldı̆̆ 1 görülmüştür. Sosyal ve Sosyo-matematiksel normlar ile yapılan çalışmaların genel olarak normların sınıf ortamındaki doğasını, yapısını ve gelişim sürecinin zamanla nasıl geliştiği ile ilgili bilgi veren kuramsal çalışmalar (Özmantar vd., 2009; Stephan ve Cobb, 2003; Yackel ve Cobb, 1996), matematik öğrenme ortamlarında sosyal ve sosyomatematiksel normların belirlenmesi için yapılan nitel çalışmalar (Van Zoest vd., 2012; Tatsis ve Koleza, 2008; Lopez ve Allal, 2007; McClain ve Cobb, 2001; Yackel, Ramussen ve King, 2000), matematik dersinde problem çözme sürecinde bilgisayar destekli araçların kullanılması sonucu ne tür normların ortaya çıkacağını belirlemeye yönelik çalışmalar (McClain ve Cobb, 2001b; Akyüz, 2014) şeklinde olduğu görülmüştür. Bu yapılan çalışmaların ise özellikle kaynaştırma öğrencilerinin öğretmenlerine yönelik olmayıp, normal sınıf ortamlarındaki öğretmen normlarının belirlenmesi ile ilgili olduğu tespit edilmiştir. Bu nedenle özellikle son zamanlarda kaynaştırma öğrencilerin öğrenme ortamlarındaki farklılıkların daha çok önem kazandığ düşünüldüğünde çalışmanın bulgularının sınıfında kaynaştırma öğrenci bulunan öğretmenlere yol gösterici olabileceği ve literatüre katkı sağlayacağ düşünülmektedir.

\section{Araştırmanın Modeli}

\section{Yöntem}

Çalışma nitel bir çalışma olup, durum çalışması yöntemi kullanılmıştır. Araştırmada birden fazla alt durumu veya birimi derinlemesine inceleyen iç içe geçmiş tek durum deseni (Yıldırım ve Şimşek, 2005) kullanılmıştır. Bu araştırmada ele alınan durum, sinıfında öğrenme güçlüğüne sahip öğrencilerin bulunduğu öğretmenlerin sayılar ve işlemler konusunda işe koştukları sosyo-matematiksel normlar iken, bu durum içerisinde yer alan alt birimler ise farklı sosyo-matematiksel normların oluşumlarını içeren diyaloglardan oluşmuştur. 


\section{Çalışma Grubu}

Bu çalışmanın asıl uygulamasının katılımcılarını 2019-2020 eğitim-öğretim yılı bahar döneminde Türkiye' nin batısındaki bir ilin ilçe merkez ve köy okulunda öğrenme güçlüğü çeken öğrencilerin bulunduğu 5. sinıflarda eğitim veren matematik öğretmenleri oluşturmuştur. Araştırmaya başlanmadan önce ilgili ilçede yer alan (köy ve merkez okullar) okulların hepsinin idare ve rehber öğretmenleriyle konuşularak hangi sinıflarda öğrenme güçlügüne sahip öğrencilerin olduğu araştırmacı tarafından tek tek tespit edilmiş ve hangi okullarda çalışma yapılacağına danışman ile birlikte karar verilmiştir. Bu bağlamda araştırma verilerinin elde edildiği örneklemin seçimi araştırma sonuçlarını temsil etme veya benzer durumlardaki anlamlılık bakımından önemli olduğu için araştırmadaki katılımcılar seçkisiz olmayan örnekleme yöntemlerinden amaçlı örnekleme yöntemine göre belirlenmiştir.

Çalışmada toplam 4 öğretmen ile çalışılmıştır. Öğretmenlerden bir tanesi pilot diğerleri ise asil katılımcı olarak belirlenmiştir. Seçilen katılımcılarla gerekli görüşmeler yapılmış ve bir öğretmen sınıfında video çekimine çekimser yaklaşması nedeniyle bu öğretmen pilot uygulama için seçilmiş, veriler gözlem yoluyla not alınmıştır. Diğer öğretmenler sınıflarında video çekimini sorun etmediği için ve aynı zamanda araştırmacıya gerekli yardımları sağlayacakları için asil katılımcı olarak belirlenmiştir. Bu çalışmada ise sadece asıl katılımcı verilerine yer verilmiştir. Öğretmenlere ve öğrenme güçlüğüne sahip öğrencilere takma isim verilerek çalışmanın etik kurallar çerçevesinde kendi isimleri kullanılmadan sunulması amaçlanmıştır. Katılımcılara ilişkin bilgiler Tablo 1'de sunulmuştur.

Tablo 1

Katılımcıların Özellikleri

Öğretmenlerin sosyo-demografik durumları

\begin{tabular}{lccc}
\hline İsim & Yaş & Öğretmenlik deneyimi & Mezun olduğu fakülte \\
& & & \\
\hline Serdar (Pilot katılımc1) & 38 & 16 & Eğitim fak. \\
\hline Emin (Asıl katılımc1) & 50 & 28 & Eğitim fak. \\
\hline Ezel (Asıl katılımc1) & 34 & 12 & Eğitim fak. \\
\hline Defne (Asıl katılımc1) & 28 & 6 & Eğitim fak. \\
\hline
\end{tabular}

Öğretmenlerin sinıflarında bulunan öğrenme güçlüğüne sahip öğrencilerin özellikleri de Tablo 2' de verilmiştir.

Özel öğrenme güçlüğü çeken öğrencilerden Arda; matematik öğretmeni tarafından iyi olarak nitelendirilmiştir. Aslında üzerine düşülse çok daha iyi olabileceği, kapasitesinin iyi olduğu, babasının cezaevinde olmasından dolayı her hafta babasını ziyarete gittikleri için dersleri düzenli olarak kaçırdığı belirtilmiştir. Arda özel gereksinimine rağmen destek odasında eğitim almamaktadır. Hale, destek odasında eğitim alan düşük matematik başarısına sahip bir öğrencisidir. Matematik öğretmeni Hale'nin derslere genel olarak katıldığını fakat kendini fazla 
zorlamadığını belirtmiştir. Yaşar ise destek odasında kendi matematik öğretmeni tarafından eğitim alan orta düzeyde matematik başarısına sahip bir öğrencidir. Yaşar'ın ailesi onun eğitimi ile son derece ilgili bir ailedir.

Tablo 2

Öğrenme Güçlüğüne Sahip Öğrencilerin Özellikleri

Öğrenci Öğretmeni Matematik ders başarısı Destek odasında eğitim Anne-Baba

\begin{tabular}{|c|c|c|c|c|c|c|c|c|c|c|}
\hline & & $\begin{array}{l}\vec{\Delta} \\
\overrightarrow{0} \\
\dot{0}\end{array}$ &.$\widehat{\Xi}$ & 䄏 & 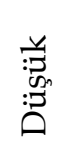 & $\underset{\text { 岕 }}{\stackrel{\vec{J}}{N}}$ & 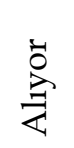 & 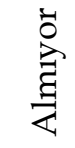 & 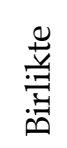 & 究 \\
\hline Arda & Defne & & $\checkmark$ & & & & & $\checkmark$ & $\checkmark$ & \\
\hline Hale & Ezel & & & & $\checkmark$ & & $\checkmark$ & & & $\checkmark$ \\
\hline Yaşar & Emin & & & $\checkmark$ & & & $\checkmark$ & & $\checkmark$ & \\
\hline
\end{tabular}

\section{Veri Toplama Süreci}

$\mathrm{Bu}$ araştırmada da veri toplamak için doküman analizi ve gözlem formundan yararlanılmıştır. Veriler görsel ve işitsel video kaydı ve gözlem formu kullanılarak toplanmıştır. Öğretmenlerin kullandıkları normları belirlemek ve bu normların sosyokültürel süreç içerisinde nasıl geliştiğini gözlemek amacıyla dersler video kaydına alınmış ve gözlem de araştırmacı tarafından gerçekleştirilmiştir.

Katılımcıları tespit ederken öğrenme güçlüğüne sahip öğrencilerin öğretmenleri tercih edildiğinden bu özelliklere uygun öğrencilerin daha çok 5 . sinıflarda olduğu görülmüş ve bu yüzden konu ile ilgili kayıtların yapılabilmesi için öncesinde beşinci sınıf matematik öğretim programında yer alan öğrenme alanları ve alt öğrenme alanları incelenmiştir. Bu öğrenme alanlarının ilki olan sayılar ve işlemler tercih edilmiştir. Tez uygulamasının zamanlaması olarak da kesirler ve kesirlerle işlemlerle ilgili kazanımların ele alınması uygun görülmüştür. Bu makale çalışmasında ise kesirlerle işlemlerin Tablo 3' deki kazanımları ele alınmıştır.

Tablo 3

Her Bir Veri Kaydı ve Gözlem Formu için Belirlenen Alt Öğrenme Alanı ve Kazanımlar

\begin{tabular}{lcl}
\hline Alt Öğrenme Alanı & Kazanımlar \\
\hline Kesirlerle İşlemler & $\begin{array}{l}\text { Paydaları eşit veya birinin paydası diğerinin paydasının katı } \\
\text { olan iki kesrin toplama ve çıkarma işlemini yapar ve } \\
\text { anlamlandırır. }\end{array}$ \\
$\begin{array}{l}\text { Paydaları eşit veya birinin paydası diğerinin paydasının katı } \\
\text { olan olan kesirlerle toplama ve çıarma işlemleri gerektiren } \\
\text { problemleri çözer ve kurar. }\end{array}$ \\
\hline
\end{tabular}

Derslerin video kayıtları. Araştırmada öncelikle pilot çalışmanın yapılacağı öğretmenin hangi öğretmen olacağına karar verilmiştir. Bu pilot çalışma köyde çalışan 5. sınıflarda derse giren bir matematik öğretmenidir. Pilot çalışmada tek kamera kullanılmıştır. Tek kamera perspektifinde özel öğrenme güçlüğüne sahip öğrenci ve öğretmen olacak şekilde 3 ders saati bir kamera çekim kaydı yapılmıştır. Daha sonra bu kayıtlar araştırmacı ve danışman tarafından izlenerek kamera sayısının 2'ye çıkarılmasına karar verilmiştir. Birinci kamera ile öğrenme güçlüğüne 
sahip öğrenci ve öğretmenin izlenmesine, ikinci kamera ile de sinıf genelinin izlenilmesine karar verilmiştir.

Çalışmada Tablo 3'deki kazanımların her biri için her matematik öğretmeninin üçer saatlik dersinin video çekimi yapılmıştır. Dolayısıyla her bir öğretmen için toplam altı ders saati olacak şekilde üç öğretmenin toplamda 18 saat video kaydı ve gözlemi gerçekleştirilmiştir. Video kayıtları araştırmacı tarafından gerçekleştirilmiştir. Kameralar perspektif ayarlama veya net görüntü elde etmek için öğrencilerin dikkatini dağıtmayacak şekilde yerleştirilmiştir.

Gözlemci notları. Çalışmada araştırmacı sınıfa herhangi bir müdahalede bulunmadan tamamen gözlem yapmıştır. Bu süreçte araştırmacıya göre sınıf mikro kültüründe ortaya çıkan söylemler ve davranışların sosyo-matematiksel normların belirlenmesinde etkili olacağı düşünülerek gerekli notlar alınmıştır. Bu notlar video kayıtları incelenirken göz önünde bulundurulmuştur.

Uygulama süreci. Çalışma verileri 2019/2020 eğitim-öğretim yılının ikinci dönemini kapsayan 3 haftalık bir süreçte her biri haftada 2 saat olan ders oturumlarından elde edilmiştir. Veri toplama sürecinde öğrencilerin ve öğretmenin doğal sınıf ortamından veri toplamak için araştırmacı tarafından sınıfta video çekimleri yapılmıştır. Öğrencilerin ve öğretmenlerin ilk çekimlerde biraz gerildikleri, doğallıktan uzak oldukları fakat daha sonraki çekimlerde video kaydına alıştıkları görülmüsstür. Bu sebeple sınıf ortamında öğrencileri kameraya alıştırma çalışmaları yapılmış ve doğal ortam süreci yakalandiktan sonra asıl amaçlanan video çekimlerine başlanmıştır. Dersler kayıt altına alınmadan önce araştırmacı tarafından her ders başı kameraların yerleşimi ve gerekli araç-gereçler hazır hale getirilmiştir.

\section{Verilerin Analizi}

Öğrencilerin video kayıtları ve gözlemcinin notları ile elde edilen veriler içerik analizi kullanılarak analiz edilmiştir. Veri analizinin ilk aşamasında video kayıtlarından elde edilen veriler transkript edilerek yazılı metne dökülmüştür. Diyaloglarda öğretmenlere ve öğrencilere takma isim verilmiştir. Metinlerdeki diyaloglar tekrar tekrar gözden geçirilerek sosyomatematiksel norm oluşturan veriler kodlanmıştır. Bunun sonucunda belirlenen kodların benzer ve farklı yönlerinin incelenmesi sonucunda temalar oluşturulmuştur. Verilerin içerik analizi sonucu sosyomatematiksel norm olabilecek her bir norm belirlenmiştir. Akyüz (2014)'e göre bir davranışın norm olabilmesi için sıklıkla tekrar etmesi gerekmektedir. Aynı zamanda Park (2015) çalışmasına göre bir davranışın en az üç kez tekrar ettiğini gözlemlemek, o davranışı anlamak için yeterli olacaktır. Bu bağlamda normlar tespit edilirken hangi sıklıkla ortaya konulduklarına dikkat edilmiştir. Bu bağlamda hem sosyomatematiksel normları belirlemede hem de normların oluşum sürecinde alan yazındaki yapılan çalışmalarda (Güven ve Dede, 2017; Sanchez ve Garcia, 2014; Sfard, 2008; Sekiguchi, 2005; Cobb ve Whitenack, 1996) ortaya konan normlar temel alınmıştır.

$\mathrm{Bu}$ yaklaşımlara göre;

1. Transkriptler üzerinden tekrar eden öğrenci ve öğretmen davranışları belirlenmiş,

2. Video kayıtlarının transkriptler üzerinden sıkça tekrar eden (en az üç tekrar) davranışların norm, sık tekrar edilmeyenlerin ise norm olmaya aday olarak belirlenmesi sağlanmış, 
3. Gerekli matematiksel becerileri içeren davranışlar öğretmen ve öğrencinin müzakeresi sonucu oluşmuşsa sosyomatematiksel norm olarak kabul edilmiştir.

Verilerin analizinde veriler önce ilk araştırmacı tarafından ardından ikinci araştırmacı tarafından incelenerek kodlama yapılmış ve kodlama güvenirliği \%95 olarak bulunmuştur. Görüş ayrılığı olan kodlar araştırmacılar tarafından tartışılarak görüş ayrılığı olan kodlamalarda görüş birliğine varılmış ve güvenirlik sağlanmıştır.

\section{Araştırmanın Etik İzinleri}

Yapılan bu çalışmada “Yükseköğretim Kurumları Bilimsel Araştırma ve Yayın Etiği Yönergesi" kapsamında uyulması belirtilen tüm kurallara uyulmuştur. Yönergenin ikinci bölümü olan "Bilimsel Araştırma ve Yayın Etiğine Aykırı Eylemler" başlığı altında belirtilen eylemlerden hiçbiri gerçekleştirilmemiştir.

Etik kurul izin bilgileri

Etik değerlendirmeyi yapan kurul ad $1=$ Uşak Üniversitesi Sosyal ve Beşeri Bilimler Bilimsel Araştırma ve Yayın Etiği Kurulu

Etik değerlendirme kararının tarihi=13.02.2020

Etik değerlendirme belgesi sayı numarası= 89784354-050.99-

Çalışmadaki verilerden, veri analizinde belirtilen yöntem kullanılarak sosyomatematiksel norm olabilecek davranışlar bu bölümde paylaşılmıştır. Öğretmenlerin sınıf içerisinde oluşturmayı amaçladıkları sosyomatematiksel normlar ve bu normlara ilişkin açıklamalar ile hangi öğretmenlerin bu normları kullandığı Tablo 4'de verilmiştir.

Tablo 4 incelendiğinde farklı öğretmenlerde benzer sosyomatematiksel normlara rastlanmasına rağmen faklı sosyomatiksel normların da ortaya çıktığ görülmüştür. Cobb ve Yackel (1996) bunun sebebini her öğretmenin farklı sinıf mikrokültürüne sahip olmasına bağlamıştır. Farklı sınıf mikrokültürünün ortaya çıkmasındaki en büyük etken öğretmenlerin farklı inanç ve değerlere sahip olmasıdır. Öğretmen normların belirlenmesinde merkezi bir role sahiptir. Öğretmen sınıfında nelerin kabul edilebilir davranışlar olduğunu göstererek, sınıfında kurmak istediği sosyomatematiksel normları oluşturur. Sosyomatematiksel normlar bir matematik sınıfındaki öğrenme ve öğretme etkinlilerinin kalitesini belirler. Bu bağlamda öğretmenlerin öğrenme güçlüğü çeken öğrencilerin öğrenme ve öğretme kalitesini belirlemek için ortaya çıkan sosyomatematiksel normların açıklamalarına ve diyaloglarına daha detaylı bakılmıştır. 
Tablo 4

Öğretmenlerin Oluşturmaya Çalıştığı Sosyo-matematiksel Normlar ve Açıklamaları

\begin{tabular}{|c|c|c|c|c|}
\hline Sosyo-matematiksel Normlar & Açıklama & Defne & Ezel & Emin \\
\hline $\begin{array}{l}\text { Matematiksel anlamda farklı } \\
\text { çözümler gösterme }\end{array}$ & $\begin{array}{l}\text { Öğretmen bir çözüm yolunu } \\
\text { diğerinden matematiksel anlamda } \\
\text { farklı kılan sseyin ne olduğunu } \\
\text { gösterir ve öğrenciler buna göre } \\
\text { hareket ederler. }\end{array}$ & & $\checkmark$ & $\checkmark$ \\
\hline $\begin{array}{l}\text { Gerekçelendirmeden } \\
\text { matematiksel açıklamayı kabul } \\
\text { etme }\end{array}$ & $\begin{array}{l}\text { Bir açılamanın } \quad \text { gerekçe } \\
\text { gösterilmeden öğretmen tarafından } \\
\text { kabul edilmesidir. }\end{array}$ & $\checkmark$ & $\sqrt{ }$ & \\
\hline $\begin{array}{l}\text { Sınıfta ortaya atılan } \\
\text { matematiksel muhakemeleri } \\
\text { gerekli sorgulamalarla masaya } \\
\text { yatırı tartışarak bir uzlaşmaya } \\
\text { varma }\end{array}$ & $\begin{array}{l}\text { Sınıfta ortaya atılan matematiksel } \\
\text { fikirlerin işbirliği içinde tartışılıp } \\
\text { müzakere edilmesi sonucu bir } \\
\text { uzlaşmaya varılmasıdır. }\end{array}$ & $\checkmark$ & & \\
\hline $\begin{array}{l}\text { Kabul edilebilir matematiksel } \\
\text { açıklama ve gerekçeler ortaya } \\
\text { koyma }\end{array}$ & $\begin{array}{l}\text { Yapılan açılamalar matematiksel } \\
\text { argümanlar, nedenler ve gerekçeler } \\
\text { içermelidir. }\end{array}$ & $\checkmark$ & & $\checkmark$ \\
\hline $\begin{array}{l}\text { Verilen hatalı çözümlerden } \\
\text { faydalanarak doğru çözümler } \\
\text { yapma }\end{array}$ & $\begin{array}{l}\text { Öğgrencinin hatasından yararlanarak, } \\
\text { hataları kendi avantajlarına } \\
\text { dönüştürmeleridir. }\end{array}$ & & & $\checkmark$ \\
\hline $\begin{array}{l}\text { Basit kolay ve etkili çözümler } \\
\text { sergileme }\end{array}$ & $\begin{array}{l}\text { Çözümlerin en iyi anlaşılır şekilde } \\
\text { yapılması }\end{array}$ & $\checkmark$ & $\checkmark$ & \\
\hline $\begin{array}{ll}\text { Rehberlik } & \text { ederek, doğruyu } \\
\text { buldurma } & \end{array}$ & $\begin{array}{l}\text { Öğrencilere ne yapması gerektiğini } \\
\text { tarif ederek doğru cevaba } \\
\text { ulaşmaların sağlamak. }\end{array}$ & $\checkmark$ & $\checkmark$ & $\checkmark$ \\
\hline $\begin{array}{lr}\text { Hatalı } & \text { gösterimden } \\
\text { faydalanarak genelleme yapma }\end{array}$ & 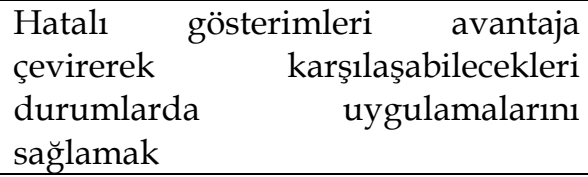 & $\checkmark$ & & \\
\hline $\begin{array}{l}\text { Bir öğrencinin çözümünü } \\
\text { yeniden açılamak ve } \\
\text { çözümleme }\end{array}$ & $\begin{array}{lrr}\begin{array}{l}\text { Öğrencinin } \\
\text { cümleleriyle } \\
\text { etmelerini sağzülamakm }\end{array} & \begin{array}{c}\text { yeniden } \\
\text { seanin }\end{array} & \begin{array}{r}\text { kendi } \\
\text { ifade }\end{array} \\
\end{array}$ & $\checkmark$ & $\checkmark$ & \\
\hline $\begin{array}{l}\text { Matematiksel doğruluğu kabul } \\
\text { edilen çözümleri yaptırma }\end{array}$ & $\begin{array}{l}\text { Hem işlemsel hem de kavramsal } \\
\text { anlamalarını sağlamak. }\end{array}$ & & & $\checkmark$ \\
\hline
\end{tabular}

\section{Matematiksel Anlamda Farklı Çözümler Gösterilmeli Normuna İlişkin Bulgular}

$\mathrm{Bu}$ norm, bir öğretmenin, öğrencinin daha iyi öğrenmesi için bir sorunun çözümü ile ilgili farklı çözüm yolları keşfettirerek öğrencilerin soru çözümünde tek bir çözüme bağlı kalmadan farklı çözüm yollarını kullanarak soru çözümünde özgür olmalarının sağlandığı durumlardır. Ezel öğretmen için bu davranış sınıfta sıkça tekrar eden bir davranış olarak belirlenmiş ve bu davranış Ezel öğretmen için bir norm olarak kabul edilmiştir. Fakat diğer öğretmenlerde bu davranış sıkça tekrar etmediği için bu davranış norm olmaya aday bir davranış olarak belirlenmiştir. Bu bağlamda aşağıda bir doğal sayıdan bir kesrin çıkarılması işlemine ilişkin Ezel öğretmen ve öğrenme güçlüğüne sahip Hale arasındaki diyaloğa yer verilmiştir:

Hale: ...Hocam birden fazla yol var.

Ezel: Evet. Birçok yoldan yapabilirsiniz... Şimdi 1. yol, 1. yolumuz 1 eksi 7/20 yazabilirsiniz. Şimdi örneğimizde 1'in altına gizli 1 çektik. Payda eşitledik. 20'de 20 oldu. 20'de 20'den, 20'de 7'yi çıkardık ne kaldı? 
Hale: 20 'de 13.

Ezel: 20'de 13 kaldı. Tamam mı? Ya da pratik yoldan yapabiliriz. Hiç payda eşitleme ile uğraşmadan 1 kere 20, 20'den 7 çıkardım, 13/20.

Yukarıdaki diyalogda Hale daha önceki yapılan örneklerden yola çıkarak birden fazla yolla sorunun çözülebileceğini belirtmiştir. Bunun üzerine öğretmen bir doğal sayıdan bir kesrin çıkarma işleminin birden fazla yolla yapilabileceğini göstermiştir. Burada öğretmen bir sorunun farklı çözüm yollarını göstererek, soru çözümü sırasında hangi yolun tercih edileceğini öğrenciye bırakmıştır. Sonuç itibari ile bir sorunun farklı yolları ile çözülebileceğinin öğretmen tarafından gösterilmesi öğrencinin daha sonraki sorularda farklı çözüm yollarının olabileceği sosyomatematiksel normunun oluşmasına zemin hazırlamıştır. Bu normun oluşmasının öğrencinin matematiksel gelişimine katkı sağlayacağı düşünülmektedir.

\section{Gerekçelendirmeden Matematiksel Açıklamayı Kabul Etme Normuna İlişkin Bulgular}

$\mathrm{Bu}$ normda öğretmenin süreçten ziyade sonuca odaklandığı görülmüştür. Yani burada öğretmen, öğrencinin sorunun cevabına ilişkin vermiş olduğu sonuca ilişkin matematiksel açıklamaları herhangi bir gerekçe istemeden kabul etmiştir. Defne öğretmen için bu davranış sınıfta sıkça tekrar eden bir davranış olarak belirlendiği için bir norm olarak kabul edilirken diğer öğrtemenlerde bu davranış sıkça tekrar etmediği için bu davranış norm olmaya aday bir davranış olarak belirlenmiştir. $\mathrm{Bu}$ bağlamda aşağıda Defne öğretmen ile öğrencisi Arda arasında geçen iki farklı diyaloga yer verilmiştir:

Defne: ...Paydaları eşitledikten sonra paydalarn eşit olan kesirlerde toplama yapabilir miyiz? (öğrenciler parmak kaldırıyor)

Arda: Yapamayız.

Defne: Peki neden yapamayız?

Arda : Pay mı demiştiniz payda mı öğretmenim?

Defne: Paydalarn eşit ise toplama yapabilir miyiz?

Arda: Mesela 2/10+4/10=6/10 yapar. Yani yapabiliriz.

Defne: Yani paydalarn toplama işleminde eşit olması gerekiyor mu?

Arda: Evet.

Yukarıdaki diyalogda öğretmen paydaları eşit olmayan kesirlerde toplama işleminin yapılıp yapılamayacağını sormuş ve Arda toplama işlemi yapılması için paydalarının eşit olması gerektiğini belirtmiştir. Ancak, bu diyalog kesitinde Arda paydaları eşit olan kesirlerde toplama işleminin neden yapılacağını herhangi bir gerekçelendirme yapmadan açıklamış ve öğretmen de cevabı o şekliyle kabul etmiştir. Bunun sebebinin öğrencilerin verdiği cevaplara karşı öğretmenin tepkisinin olduğu söylenebilir. Eğer öğretmen "neden?" veya "niçin?" gibi sorgulamaya dayalı sorular sorup bu soruların üstüne gitseydi öğrenci de ona göre cevap verebilirdi. Öğretmenin tepkisinden öğrencinin sadece soruya cevap vermesinin yeterli olduğu düşünüldüğünden ikinci diyalogda da Arda'nın sunduğu cevabına ilişkin herhangi bir gerekçe sunmamasına sebep olduğu söylenebilir. Dolayısıyla Defne öğretmenin Arda'nın vermiş olduğu cevaplar karşısındaki tepkileri gerekçelendirmeden matematiksel açıklamayı kabul etme sosyomatematiksel normunun ortaya çıkmasına sebep olmuştur. 
Sinifta Ortaya Atılan Matematiksel Muhakemeleri Gerekli Sorgulamalarla Masaya Yatırıp Tartışarak Bir Uzlaşmaya Varma Normuna İlişkin Bulgular Çalışmada öğretmenin sınıfta ortaya atılan bir matematiksel fikri işbirliği içerisinde tartışıp müzakere ederek sonucunda öğrencilerle birlikte bir uzlaşmaya vardı̆̆ görülmüştür. Öğretmenin bu tepkisi sınıf içerisinde bir tartışma ortamının yaratılması ile öğrencilerin düşüncelerini özgürce ifade etmesine katkı sağlamıştır. $\mathrm{Bu}$ özgür ortamda öğrenciler beyin fırtınası yaparak matematiksel anlamda gelişmelerine katkı sağlamışlardır. Özellikle öğrenme güçlüğüne sahip öğrencilerin de konuya ilişkin fikirlerinin herhangi bir yargılama yapılmadan alınıp dinlenmesi onların matematiğe karşı olan ilgilerinde olumlu yönde katkı sağlamıştır. Bu davranış Defne öğretmenin sınıfında bir kez ortaya çıkan bir davranış olduğu için bu davranış Defne öğretmen için norm olmaya aday bir davranış olarak kabul edilmiştir. Diğer öğretmenlerin sınıflarında ise bu davranışa izlenilen süreç içerisinde rastlanılmamıştır. Aşağıda bu norma örnek verilebilecek Defne öğretmen ve öğrencisi Arda arasındaki bir diyaloga yer verilmiştir:

Defne: ...Özlem soruyu okur musun?

Özlem: Ahmet 1 tam 1/2 pizza ve Arzu bir pizzanın 2/8'ini yemiştir. 3 tam pizza dan geriye kalan pizza ne kadardır?

Defne: Bakın dinleyin. Ahmet 1 tam 1/2 yemiş Arzu da ne yemiş?

Öğrenciler: $2 / 8$.

Defne: 2/8'ini yemiş. Arda nasıl yaparnz?

Arda: Ahmet ve Arzu'nun yediklerini toplicaz.

Defne: Neden?

Arda: Toplamin soruyor.

Defne: Arda toplamını sorduğu için toplamamı gerektiğini söyledi katılıyor musunuz?

Sinıf: Evet.

Defne: Peki Arda nasıl toplarız? Bu şekilde verilen kesirleri toplarken ne yapıyorduk?

Arda: Payda eşitleriz.

Defne: Evet, güzel. Peki nelerin paydalarm eşitlicez.

Arda: $1 / 2$ ile 2/8 'in.

Defne: Peki 1/2'nin başında 1 tam var onu napıcaz?

Arda: Onu ellemicez...

Defne: Arda diyor ki tam kısmı aynen kalır kesir kısımlarının paydasını eşitleriz doğru mudur?

Sinıf: Evet.

Defne: Evet ... Arda, çok güzel aferin oturabilirsin...

Yukarıdaki diyalogda görüldüğü üzere öğretmen, Arda'nın yaptığ1 çözüm aşamalarını sınıf geneline sunmuş ve sınıftaki arkadaşlarının da yorumlarını almıştır. Bu bağlamda öğrencilerin her biri Arda'nın yaptığı işlem adımları üzerine düşünerek öğretmene cevap vermişlerdir. Burada oluşturulan özgür sınıf ortamı bu sosyomatematiksel normun ortaya çıkmasına zemin hazırlamıştır. Bu norm öğrencilerin matematik tartışmalarına katılımını sağlaması yönüyle oldukça yararlıdır. 


\section{Kabul Edilebilir Matematiksel Açıklama Ve Gerekçeler Ortaya Koyma Normuna İlişkin Bulgular}

Geleneksel matematiksel sembollerin işlenmesi için bir prosedür belirleyerek matematiksel nesneler üzerindeki eylemlerin önemini taşımalıdır. Aynı zamanda matematiksel aktivitelerin matematiksel açıllamalarda önemi oldukça fazladır. Bu sosyomatematiksel normda öğrencilerin vermiş olduğu açıklamalarda daha çok sonuçtan çok sürece odaklanılır. Yapmış oldukları açıklamaları matematiksel semboller ve nesnelerle destekleyerek açıllamaları istenmektedir. Bu davranış Defne ve Emin öğretmenin sınıfında gözlemlenmiş fakat tekrar eden bir davranış olmadığı için bu davranış Defne ve Emin öğretmen için norm olmaya aday bir davranış olarak kabul edilmiştir. Diğer öğretmenin sınıfında ise bu davranışa izlenilen süreç içerisinde rastlanılmamıştır. Aşağıda bu norma örnek verilebilecek bir diyalog kesiti verilmiştir.

Emin: ...SSimdi problem yazaltm bir tane... Bir tiyatro oyunu biletlerinin 7de 4 ünü Yiğit satmış, 14 de 3 ünü ise Berkay satmıştır. A şıkkı biletlerin kaçta kaçı satılmıştır? Önce bu şıkkı yapalım sonra b şıkkını sorucam size.

Öğrenci: Hocam 14'te 5.

Emin: Bakayım getir.(öğrenci gösterirken Yaşar öğretmenin yanına gider elinde defter yoktur)

Yaşar: Hocam 14'te 6.

Emin: Nasıl buldun? ( Yaşar cevap vermez)

Yukarıdaki diyalogda öğretmen, Yaşar'ın yapmış olduğu açıklamayı dinlemiş ve ondan nasıl yaptığını gerekçeleriyle sunmasını istemiştir. Öğretmen için sonuç değil süreç önemlidir. Bu normda asıl dikkat edilmesi gereken nokta temelde yatan matematiksel mantığı anlamaktır. Aynı zamanda bu norm ile kavramsal öğrenmenin önemi fark ettirilmiş olur.

\section{Verilen Hatalı Çözümlerden Faydalanarak Doğru Çözümler Yapma Normuna İlişkin Bulgular}

Çalışmada öğrenme güçlüğüne sahip öğrencinin hatalı cevabından yola çıkılarak diğer öğrencilerle birlikte doğru çözüm bulunmaya çalışılmıştır. Burada verilen hatalı cevap bir fırsat olarak değerlendirilmiş ve diğer öğrenciler tarafından alternatif çözüm üretilmiştir. Bu durum da öğrencilerin matematiksel gelişimini olumlu yönde etkilemiştir. Bu davranış sadece Emin öğretmen tarafından sergilenmiş fakat bu davranış Emin öğretmenin sınıfında sıkça tekrar eden bir davranış olmadığı için norm olmaya aday bir davranış olarak kabul edilmiştir. Diğer öğretmenlerde bu davranışa izlenilen süreç içerisinde rastlanılmamıştır. Aşağıda bu norma örnek verilebilecek Emin öğretmen ve öğrencisi Yaşar arasındaki bir diyaloga yer verilmiştir:

Emin: Bunu kim yapacak (sınf parmak kaldırı)) Yaşar gel bakalım.

Yaşar: 1/2 +3/10 ... 4/12 yapar.

Emin: Şimdi... Olmaz... Paydaları eşit değilse paydalarını eşitlicez (der ve Yaşar'ın yazdığını siler). Kim eşitleyecek? (öğrenciler parmak kaldırır) Gel bakalım.

Öğrenci: 5/10+3/10.

Emin: Tamam bundan sonrası artık Yaşar yapsın.

Yaşar: 8/10. 
Emin: Evet, naptık çocuklar burada... Toplama işleminde paydalar eşit olmayan kesirlerin önce paydalarımı eşitledik, sonra sonuca payda aynı kalacak şekilde yazarak paylarmı topladik.

Yukarıdaki diyalogda öğretmen, Yaşar'ın vermiş olduğu yanlış cevabı fırsata çevirerek tüm öğrencilerin dikkatini soru üzerine çekmeyi ve sorunun nasıl yapılması gerektiği ile ilgili öğrencilerden dönüt alarak gerekli becerilerin öğrenciler tarafından kazanılıp kazanılmadığını ortaya çıkarmayı amaçlamıştır. Gözlem sırasında alınan notlara göre, Yaşar bu soruyu çözerken hata yaptığını fark etmiş ve sonra "paydalar birbirinin katı olan kesirlerde toplama işlemi" ile ilgili farklı bir soruyu doğru yapmıştır. Öğretmenin bu soruda yapmış olduğu şey öğrencilerin dikkatini soruya çekerek nasıl yapılacağının gösterilmesidir. Nitekim Yaşar da nelere dikkat etmesi gerektiğini benimsemiş ve gözlem notlarından görüldüğü üzere bunu diğer sorulara da uygulayabilmiştir.

\section{Basit, Kolay ve Etkili Çözümler Sergileme Normuna İlişkin Bulgular}

$\mathrm{Bu}$ normda öğretmen farklı sayılan çözümler arasından basit, kolay ya da verimli olarak değerlendirilebilenleri öğrenme güçlüğüne sahip öğrencilere sunmuştur. $\mathrm{Bu}$ norma göre etkili çözüm farklı şekilde gruplandırarak çözme, çözüm sürecinde çözümü kolaylaştırıcı şemalar ortaya çıarma, kalıplar ortaya çıkarma ve bu tür kendilerine özel çözüm aşamaları geliştirerek öğrenciler üzerinde iz bırakan çözümlerdir. Bu davranış Ezel ve Defne öğretmenin sınıfında gözlemlenmiş fakat izlenilen süreç içerisinde sıkça tekrar eden bir davranış olmadığından bu öğretmenler için bu davranış norm olmaya aday bir davranış olarak kabul edilmiştir. Emin öğretmenin sınıfında da bu davranışa rastlanılmamıştır. Aşağıda bu norma örnek verilebilecek Ezel öğretmen ile öğrencisi Hale arasındaki diyalog verilmiştir:

Ezel: ...1 koli yumurtanın 5'te 2'si sarı ise kaçta kaçı beyazdır?

Sinif: Hocam yapalim mi?

Ezel: Siz defterinize çz̈zün. Sonra getirip bana gösterin ben doğru mu diye bakayım.

Hale: Öğretmenim. Ben yapamadım...

Ezel: Hale bak şöyle yapabilirsin. Bir koli yumurtanın 5'te 2'si sarn... Bir şekil çizelim 5'e bölelim... 5'te 2'si sarımmıs... Bu 5'e böldüğümü̈z şeklin 2'sini alahm bunlar sarıymış... Kaçı beyaz olur peki?

Hale: 3.

Ezel: 3 beyazmış peki tamamı kaç?

Hale:5.

Ezel: Kaçta kaçı dediği için kesir olarak nasıl ifade ederiz.

Hale: 5 'te 3.

Ezel: Şimdi bunu şöyle de yapabiliriz. Bütün den yani 1'den 5'te 2'yi çıkarıcaz. 1 kere 5 ... 5'ten 2 çıkarıyorum.

Hale: $3 / 5$.

Ezel: Evet 1'den 2/5'i çıarıyorum...pratik yoldan yapıyorum hemen..1 kere 5 ...5'den 2'yi çıkardım...3/5...ya da 5/5'ten 2/5'i çıkart...Ya da hocam hiç yapamadım...Bir şekil çiz 5 parçaya böl 2'sini boya. Kalanı bul.

Yukarıdaki diyalogda Ezel öğretmen bir sorunun birden fazla yolla çözülebileceğini öğrencisi Hale'ye anlatmış ve bu yolları anlatırken de öğrenci için basit ve etkili çözümlerin neler olabileceğine vurgu yapmıştır. Öğretmen bu tepkisiyle burada önemli olanın çözümün kullanışlı ve etkili olması olduğunu ima 
etmiştir. Öğretmenin belirttiği "ya da hocam hiç yapamadım, bir şekil çiz 5 parçaya böl 2'sini boya. Kalanı bul." son açılaması ile problemin daha rahat bir yoldan çözülmesinin üzerinde durmuştur.

\section{Rehberlik Ederek, Doğruyu Buldurma Normuna İlişkin Bulgular}

$\mathrm{Bu}$ norm, "öğretmenin akademik ve teknik açıdan yardım etmesi" sosyal normunun sonucunda ortaya çıkmıştır. Bu normda öğretmen, bilgiyi anlamlı şekilde yapılandırmaları sürecinde öğrenme güçlüğüne sahip öğrencisine yardımc1 olmuştur. Bu norm kapsamında öğretmen öğrencilere akademik açıdan yardım sağlayarak öğrenci ile etkileşimi sonucunda sorunun çözülmesine katk1 sağlamaktadır. Bu davranış tüm öğretmenlerin sınıfında gözlemlenmiş fakat izlenilen süreç içerisinde sıkça tekrar eden bir davranış olmadığı için norm olmaya aday bir davranış olarak kabul edilmiştir. Aşağıda bu norma örnek verilebilecek bir diyalog kesiti verilmiştir.

Defne: ... Nazife parasının 18/20'sini harcasaydı geriye parasının kaçta kaçı kalırdı? Şimdi 18/20'sini harcamış.

Defne: Bir şekil çiziyorum ve 20 parçaya bölüyorum. Bu arkadaşımız yani Nazife 18 parçasını ne yapmış?

Sınıf: Harcamış.

Defne: Evet. Harcamış. 18'lik harcadığı kısmı renkli kalemle gösterelim. Ne yapryoruz?

Sinif: 18 kutuyu boyucaz.

Defne: 18 parçasını tarayalım. Kırmızı ile taradığım yerleri Arda ne yapmış?

Arda: Okumuş.

Defne: O zaman Arda bize okumadiğı yani kalan yerleri soruyordu? Şimdi 20 kutunun 18 tanesini okursam geriye kaç kutum kalır?

Arda: 2.

Defne: Evet güzel. Peki bize kaçta kaçı kalmıştır diyor. Bu senin söylediğin kısmı da siyah kalemle tarayalım... Nazife'nin kitabının kaçta kaçı kalmıştır?

Arda: 2.

Defne: 2 nedir?

Arda: Okunmayan.

Defne: Evet, okunmayan... Ama bizden kesir olarak ifade etmemizi istiyor. Bütünümüz kaç parçaydı?

Arda: 20.

Defne: Peki okunmayan yani siyah iken boyanan yer kaç parça?

Arda: 2.

Defne: 20'nin 2'si okunmayan yani siyah ile boyanan yer ise bunu kesir olarak ifade etsek nasil ifade ederiz?

Arda: 20 'de 2.

Defne: Evet. Çok güzel, aferin. Oturabilirsin.

Yukarıdaki diyalogtan da görüleceği üzere öğretmen her adımda öğrenciye rehberlik etmiş, öğrenciye akademik ve teknik açıdan destek sağlamıştır. Öğrencinin ilgili soru çözümüne ilişkin olarak öğretmen her aşamada yer alarak öğrencinin düşüncelerini ortaya çıkarmıştır. Burada önemli olan sonuçtan ziyade süreçtir. Soru çözümünün aşamaları tek tek irdelenmiş yapılan işlemlerin ne anlama geldiği 
aktarılmıştır. Bu norm ile öğrencilerde kavramsal öğrenmenin oluşmasına katkı sağlanmıştır.

\section{Hatalı Gösterimden Faydalanarak Genelleme Yapma Normuna İlişkin Bulgular}

Öğretmen öğrenme güçlüğüne sahip öğrencinin yaptığı hatalı gösterimden yararlanarak konu ile ilgili genelleme yapmıştır. Bu normda ideal bir matematiksel çözümün tüm durumlar için geçerli olması fikrine ait ortak eylemler ve söylemler ortaya konulmuştur. Bu davranış Defne öğretmenin sınıfında gözlemlenmiş fakat sıkça tekrar eden bir davranış olmadığı için norm olmaya aday bir davranış olarak kabul edilmiştir. Diğer öğretmenlerde bu davranışa izlenilen süreç içerisinde rastlanılmamıştır. Aşağıda bu norma örnek verilebilecek bir diyalog kesiti verilmiştir.

Defne: ...Pekiii... bir soru daha 6/8 artı 3/2 ... Kim yapacak?(öğrenciler el kaldırır Arda da el kaldırır... Bir önceki örneklerde el kaldırmamıştı) Arda gel bakalım.

Arda: Öğretmenim bunu yapıyorum değil mi?

Defne: Evet.

Arda: 3/2'nin altına 4 yazarm. (Arda 3/2'yi 4 ile genişlettikten sonra eşittir yazar ve sorunun devaminda önce genişlettiği kesri 12/8 yazar artı der 6/8 yazar...ögrretmen bunun üzerine hemen Arda'nın yanına gelir Arda'yı kenara çeker veeee...)

Defne: Bakar misını tahtaya? Sinıf tahtaya bak lütfen... Şimdi benim yazdı̆̆ım soruda yani mavi kalem ile yazan kısımda ilk kesir hangisi?

Sinif: $7 / 6$.

Defne: Evet $7 / 6$... Peki Arda'nın yazdiğı ilk kesir ne?

Öğrenci: Öğretmenim o, ikinci kesri yazmış önce...

Defne: Evet.

Öğrenci: Hocam o yanlış yapmış...

Defne: Bu şekilde yazmak toplama da yanlış olmaz bu şekilde yazabilirsiniz fakat söz konusu çıkarma olduğu zaman sıra önemlidir. İlk kesir ne ise eğer genişletme yapmadıysan ilk kesri aynen yazarsın. Burada toplama olduğu için kesirlerin sırası önemli değildir. Ama çıkarma işleminde bu şekilde bir sıra değişikliği yapamayız. İşlemimizin sonucu yanlış çıkar. Aferin Arda güzel bir noktaya değindik sayende... Devam edebilirsin...(Arda tahtada işlem yapar ve sonucu 18/8 yazar)

Defne: Bitti mi Arda (Arda kafa sallar)..tamam oturabilirsin..

Yukarıdaki diyalogda görüldüğü üzere öğretmen, Arda'nın yapmış olduğu gösterime dikkat çekmiştir. Modellenen işlemlerin kesre dönüştürülmesi sırasında toplama işleminde sıranın önemli olmadığını fakat çıkarma işleminde sıranın önemli olduğunu vurgulamıştır. Bu bağlamda daha sonra genelleme yapılarak buna benzer soruların çözümünde toplama işleminde sıranın çok önemli olmadığ1 fakat çıkarma işleminde sıranın önemli olduğu vurgulanarak bu normun ortaya çıkması sağlanmıştır. Bunun sonucu olarak öğretmenin göstermiş olduğu tepki dikkate alındığında ideal bir çözüm için tüm durumlara ait yapılan söyleminin bu normun oluşumuna katkı sağladığı söylenebilir.

\section{Bir Öğrencinin Çözümünü Yeniden Açıklama ve Çözümleme Normuna İlişkin Bulgular}

$\mathrm{Bu}$ normda öğretmen, öğrencilerin çözümlerini kendi cümleleriyle yeniden açıklamayı ve çözümlemeyi sürdürmüştür. Öğrenciler bazen doğru düşünmelerine 
rağmen ifade etmede yetersiz kalabilmektedirler. Öğretmenin, öğrencinin yapmış olduğu işlem adımlarını detaylandırması ve işlemi yeniden anlatması öğrencilerin matematiksel mantıklarının gelişmesine katkı sağlamıştır. Bu davranış Defne ve Ezel öğretmenin sınıfında gözlemlenmiş fakat tekrar eden bir davranış olmadığı için bu davranış Defne ve Ezel öğretmen için norm olmaya aday bir davranış olarak kabul edilmiştir. Diğer öğretmenin sınıfında bu davranışa rastlanılmamıştır. Aşağıda bu norma örnek olarak Defne öğretmen ve öğrencisi Arda arasındaki bir diyalog kesiti verilmiştir.

Defne: ...4/3+1/10...Ela bu soruyu yapacak olsan nasıl yaparsin?

Ela: Toplarm.

Defne: Ama toplama derken ne yapman lazım...(Ela cevap vermeyince simıftakiler parmak kaldıriyor). Evet, Arda gel bakalım sen yap.

Arda: Çapraz yaparm.

Defne: Evet arkadaşınız çapraz yaparak paydayı genişletiyor.

Arda: Öğretmenim..40/30 + 3/30 yapar. Toplicaz.

Defne : Evet. Paydalar eşit ise toplarız diyor Arda... Topladıkkk veee 53... Arda 40

ile 3 topladı̆̆ımızda 53 mü yapar?

Arda: Himmmm....

Defne: Kaç olur?

Arda: 43. (tahtaya yazdı̆̆ını silip 43 yazar)

Defne: Evet. Güzel..

Yukarıdaki diyalog incelendiğinde öğretmen soruyu öncelikle sınıftaki öğrencilerden kaynaştırma öğrencisi olmayan Ela'ya sormuş ve öğrenciden cevap gelmemesi üzerine sınıfta parmak kaldıranlar arasında Arda'nın da olduğunu fark ederek öğrenme güçlüğüne sahip Arda'ya söz hakkı vermiştir. Öğretmen, Arda'nın cevabını yeniden açıklarken ve çözümlerken; yapılan işlem basamaklarını detaylı olarak anlatmış ve Arda'nın soruyu çözerken toplamada yaptığı hatasını da fark etmiş ve Arda'ya gerekli geri dönütleri vererek çözümü yeniden düşünmesini sağlamıştır. Gerekli dönütlerin zaman kaybetmeden verilmesi öğrencinin soru üzerindeki hakimiyetinin devam etmesini sağlamış ve işlem aşamalarını eksiksiz bir şekilde tamamlamasına yardımcı olmuştur.

\section{Matematiksel Doğruluğu Kabul Edilen Çözümlerin Yaptırılması Normuna İlişkin Bulgular}

Bireyler parçaları olduğu sosyal ve matematiksel bağlama katkı sağlarken süreçte yaptıkları dikkate alınır; ancak kendi öğrenmelerini bilişsel olarak yeniden düzenlerken nasıl bir yanıta ulaştıkları önem kazanır (Stephan ve Cobb, 2003). Bu norm bağlamında öğretmen öğrenme güçlüğü çeken öğrenciye matematiksel olarak geçerli kabul edilen çözümleri yaptırmaya çalışmıştır. Bu durumda öğrencilerin süreç içerisinde nasıl düşündükleri ve nasıl bir sonuca ulaştıkları dikkate alınır. Bu davranış Emin öğretmenin sınıfında bir kez ortaya çıkan bir davranış olduğu için bu davranış Emin öğretmen için norm olmaya aday bir davranış olarak kabul edilmiştir. Diğer öğretmenlerin sınıfında bu davranışa rastlanılmamıştır. Aşağıda Emin öğretmen ve öğrencileri ve özellikle Yaşar arasında geçen diyaloğa uygun bir örnek verilmiştir:

Emin: ...Şimdi tahtaya sorular yazayım, sizde yapın tamam mı?

Öğrenciler: Tamam 
Emin: Defterinize yapin getirin gösterin .

Yaşar: (Yaşar defterine yapar gösterir... Ama çıkarma yerine toplama yaptığı için yanlış yapmıştır.)

Öğretmen :Yaşar'a çıkarma işlemi bunlar toplama değil (Yaşar yerine gelerek tekrar yeniden yapmaya başlar) (Yaşar sonra düzenler tekrar gider)

Emin: Aferin hadi yap bakalım tahtada.

Yaşar: $4 / 5-2 / 5=2 / 5$.

Yukarıdaki diyalogda görüldüğü üzere öğretmen önce yönlendirmeleriyle öğrencilerinin, özellikle Yaşar'ın doğru çözüme ulaşmasını sağlamış ve daha sonra doğru olduğunu onayladığı çözümleri tahtada yapmıştır. Öğretmen, öğrencilerin çözüm önerileri ve açıklamalarının uygunluğu ve etkinliği hakkında kendi duygu ve düşüncelerini dile getirmiştir. Bu normda öğretmen doğru yapılan çözümlerin tahtada yapılabileceği normunun ortaya çıkmasına katkı sağladığı söylenebilir.

\section{Tartışma, Sonuç ve Öneriler}

$\mathrm{Bu}$ çalışmada öğrenme güçlüğüne sahip kaynaştırma öğrencilerine yönelik sınıf ortamında öğretmenin oluşturmaya çalıştığı sosyomatematiksel normları ortaya çıkarmak ve matematiksel ögrrenmenin aktif bireysel yapılanma ve kültürleşme süreci olarak nasıl gerçekleştiğini görmek amaçlanmıştır. Sosyomatematiksel normlar sinıf topluluğundakilerin (öğretmen ve öğrenciler) ortaklaşa kabul ettiği ortak ya da kolektif olarak sınıf faaliyetlerini düzenleyen anlayışlardır (Yackel ve Cobb, 1996). Bu çalışmada da problemlere ait çözümlerin kaynaştırma öğrencileriyle onların matematik öğretmenleri arasında gerçekleşen matematiksel tartışmalarla ortaya çıkan normatif anlayışların sosyomatematiksel normların oluşumuna katkı sağladığı gözlemlenmiştir. Belirlenen bu normların sınıf içerisinde öğrenme ortamının oluşmasına katkı sağladığı muhakkaktır. Bu çalışmada sınıf öğretim deneyi dikkate alınarak öğretmen ve öğrenciler tarafından sınıf mikrokültüründe ortaya çıkan diyaloglar analiz edilerek ortaya çıan sosyomatematiksel normlar dikkate alınmıştır.

Araştırmada öğretmenlerin genel olarak sınıflarında norm oluşturmaya çalıştıkları aday normların olduğu belirlenmiştir. Sadece matematiksel anlamda farklı çözümler gösterme ve gerekçelendirmeden matematiksel açıklamayı kabul etme davranışlarının norm, diğerlerinin ise norm adayı olduğu belirlenmiştir. Aslında norm olmaya aday davranışlar süreç içerisinde uygun ortamın oluşturulması durumunda norma dönüşebilirdi. Yani, öğrencilere uygun ortam ve gerekli zaman verilseydi bu davranışlar sıkça tekrar edilebilirdi. Örneğin; Emin öğretmen, dersinin başlarında kaynaştırma öğrencisinden yaptığı açıklamasının gerekçesini istemiş fakat öğrenci cevap vermemiştir. Burada öğrenme güçlüğüne sahip öğrencinin çok fazla konuşmak istememesi, çekinik kalması, dikkatinin çabuk dağılması gibi dezavantajlardan dolayı öğretmenin gerekçe isteme davranışı sürdürülememiş olabilir. Dolayısıyla davranış norm olabilecekken norm adayı olarak kalmıştır denilebilir. Genel anlamda da bu tür sebeplerden dolayı aslında öğretmenlerin sınıflarında oluşturmaya çalıştıkları normların bazılarının öğretmenler için norm adayı olarak kaldığı söylenilebilir.

Araştırmanın sonuçlarından biri öğretmenlerin sınıf içerisinde oluşturmayı amaçladıkları sosyomatematiksel normların bazılarının alan yazındaki normlarda da yer alan normlar olduğudur. Örneğin, çalışmada kaynaştırma öğretmeni problemleri 
birden fazla yolla çözerek daha önceden alan yazında yer alan matematiksel anlamda farklı çözümler göstermek normunu kullanmıştır. Bu normun sınıf ortamında ortaya çıkması şaşırtıcı bir durum değildir. Bazen çözümlerin tek bir yolla değil birden fazla yolla çözülmesi öğrencilerin konuyu daha iyi anlamasına ve hatta kavramsal öğrenimine katkı sağlayacağından genellikle öğretmenlerin tercih ettikleri bir norm olmuştur. Benzer şekilde bu norm alan yazındaki birçok çalışmada da (Cobb ve Yackel, 1996; Lopez ve Allal, 2007; Mcclain ve Cobb, 2001) görülmüştür. Yackel ve Cobb (1996)'a göre farklı çözüm yollarının gösterilmesi öğrencilerin üst düzey bilişsel öğrenmelerine katkı sağlamaktadır aynı zamanda öğrencilerin öğrenmelerine önemli ölçüde katkı sağlamaktadır. Nitekim bu çalışmada kaynaştırma öğretmenleri sınıflarında bu normu oluşturmaya çalışarak öğrenme güçlüğüne sahip öğrencilerinin öğrenmelerini de kolaylaştırmaya çalışmış fakat davranış norm adayı olarak kalmıştır.

Çalışmada belirlenen yani öğretmenlerin oluşturmayı amaçladığı bir diğer sosyomatematiksel norm kabul edilebilir matematiksel açıklama ve gerekçeler ortaya koymadır. Bu normda önemli olan sadece cevabı vermek değildir (Toluk-Uçar, 2016). Bir matematiksel açıklama ve gerekçelendirmenin kabul edilmesi için matematiksel ifadelerin nasıl kullanıldığının ve neden kullanıldığının birlikte açıklanması gereklidir (McClain ve Cobb, 2001). Öğretmen öğrencinin verdiği cevab1 sorgulayarak aslında öğrencilerden de sunulan şeyin hemen olduğu gibi kabul edilmemesi gerektiğini, kabul edilebilecek ve edilemeyecek davranışların olduğunu öğrencilere hissettirmektedir. Bu bağlamda, kaynaştırma öğretmeninin bu çalışmadaki rolünün enstrümental orkestrasyon kavramıyla da ilişkilendirilebileceği (Trouche, 2004) söylenebilir. Ayrıca çalışmada öğretmen öğrencilerin yaptığı açıklamaları tek başına yeterli görmeyerek, bunların altında yatan prensiplerin anlaşılmasını sağlayacak uyarılarda bulunarak da doğru bir yaklaşım sergilemiştir. Çünkü doğru cevap her zaman doğru düşüncenin ürünü olmadığ1 gibi yanlış cevaplar da kolaylikla düzeltilebilecek hatalardan kaynaklanabilir (Van de Walle, Karp ve Bay Williams, 2014). Özellikle öğrenme güçlüğüne sahip öğrencilerin daha fazla konuşmaya teşvik edilmesi ile onların düşüncelerinin arkasında yatabilen basit yanlışlar da rahatlıkla düzeltilebilir. Alan yazındaki kaynaştırma olmayan diğer öğrencilerle yapılmış birçok çalışmada (Cobb ve Yacel, 1996; McClain ve Cobb, 2001; Van Zoest, Stockero ve Taylor, 2012) sınıf mikro kültüründe bu norma rastlanmıştır. $\mathrm{Bu}$ normun aksine çalışmada gerekçelendirmeden matematiksel açıklamayı kabul etme normunu kullanan öğretmenin de olduğu görülmüş ve hatta bu davranışın norm olduğu belirlenmiştir. Bu normu kullanmayı tercih eden öğretmen, öğrencilerin sadece elde edilen sonucu ile değil özellikle onları cevaba götüren gerekçelerle ilgilenmiştir. Öğretmen altta yatan gerekçenin ne olduğunu sorgulamıştır. Özellikle matematiksel farklılıklar ve benzerlikler bakımından açıklamaların gerekçelendirilmesi çok önemlidir. Tatsis ve Koleza (2008), öğrenme ortamında yanıtları gerekçelendirmenin önemine vurgu yapmış, Clark, Moore, ve Carlson (2008), çalışmasında düşüncelerin gerekçelerle sunulmasının bir probleme yanıt ararken önemli olduğunu ve anlamlı öğrenmenin gerçekleştiği ortamlar olduğunu vurgulamıştır. Buna rağmen 2018 matematik öğretim programında matematiksel açıllamalara gerekçe istemeye çok az yer verildiği söylenebilir. Gerekçelendirmeden matematiksel açıklamaları kabul eden öğretmenler olduğu gibi 
araştırmada sınıfta ortaya atılan matematiksel muhakemeleri gerekli sorgulamalarla masaya yatırıp tartışarak bir uzlaşmaya varma normunu oluşturmaya çalışan öğretmenlerin de olduğu belirlenmiştir. Yani çalışmadaki kaynaştırma öğretmeni öğrencilerin öne sürdüğü fikirleri tartışmaya açarak ortak bir fikirde uzlaşmalarını sağlamış bu süreçte öğretmen öğrencilerde sorgulama oluşmasını sağlayıp bulunan farklı çözümleri etkili bir şekilde tartışıp çözümleri netleştirerek öğrencilerin sonuca varmalarında önemli bir rol oynamıştır. Nitekim öğretim programı matematik öğrenme ortamının öğrencilerin sorgulama yapabileceği, iletişim kurabilecekleri, eleştirel düşünebilecekleri, fikirlerini rahatça paylaşıp farklı fikirleri sunabilecekleri şekilde tasarlanması gerektiğini önermiştir (MEB, 2018). Öğretmen öğrenciler tarafından ortaya atılan çözümlerin hatalı olması ve hatta doğru olması durumunda dahi ilgili görüşleri sınıf ortamında tartışarak, öğrenme güçlügüune sahip öğrencinin yanı sıra tüm sınıfın görüşünü de almış ve sınıf olarak ortak bir sonuca varmışlardır. Öyle ki konuya ilişkin öğrencinin kafasında soru işaretleri varsa öğrencinin konuyu tam olarak öğrenmesi beklenilmez. Bunun yanısıra ilgili çözümlerin tartışılması her öğrenciye fikrinin değerli olduğu hissini de verebilir. Ayrıca bu tarz bir sınıf mikro kültüründe demokratik ortamın varlığından söz edilebilir. Öğretmenin sağladığı bu demokratik ortamin öğrenme güçlüğüne sahip öğrencinin sınıfta düşüncelerini özgürce ifade edebilmesini sağlama açısından oldukça önemli olduğu söylenebilir. Nitekim Levenson, Tirosh ve Tsamir (2009), işbirliği olan matematik sınıflarında demokratik katılım yapısının normların oluşumuna zemin hazırladı̆̆ını belirtmiştir. Benzer şekilde bu norm alan yazındaki çalışmalarda da (Cobb ve Yackel, 1996; Kazemi 2008) görülmüştür.

Çalışmada kaynaştırma öğretmeninin sınıfında oluşturmayı amaçladı̆̆ı normlardan birisi de verilen hatalı çözümlerden faydalanarak doğru çözümler yapma olmuştur. Bu norm öğrencilerin matematikteki birçok tanım ve formülü anlama sürecinde ortaya çıkabilecek hatalı durumları avantaja çevirerek, öğrencilerin dikkatini çeken etkin olan yolları bulmalarını sağlamaktadır. Matematikte önemli olan her zaman doğru cevabı vermek değildir. Hatalı çözüm üzerinden gidilerek aslında çözüm adımlarında öğrenciyi hataya götüren nedenlerin neler olduğu tartışılarak doğruya ulaşılabilir ki bu durum öğrencinin konuyu anlamasında daha etkili olabilir. Öyle ki Sekiguchi (2015) de bazen yanlış olarak nitelendirilen çözümler üzerinden gidilerek öğrenciler için çok daha verimli olabilecek çözümlere ulaşılabileceğini iddia etmiştir. Aynı zamanda Kazemi (2008)'nin çalışmasında da bu norm görülmüştür. Unutmamak gerekir ki birçok matematiksel ispatlar hatalı veya başarısız çözümler sonucu ortaya çıkmıştır. Çalışmada bu norma benzer olarak oluşturulması amaçlanan bir diğer norm da hatalı gösterimden faydalanarak genelleme yapma normudur. Bu normu işe koşan öğretmen öğrencisinin ortaya koyduğu hatalı çözümden yararlanarak farklı bir durumla ilgili genelleme yapmıştır. Gülburnu (2019) da problem çözümlerinin tartışıldığ1 bir ortamda bu normun oluştuğunu çalışmasında ortaya koymuştur. Bu normun aksine Güven ve Dede (2017), çalışmalarında bir veya iki örnek vermek, matematiksel soyutlama için yeterli kabul edilmez normunu öğretmenlerin kullandığını, yani birkaç örnekle genellemeye varılamayacağını ortaya koymuştur.

Bir öğrencinin çözümünü yeniden açıklamak ve çözümlemek normu çalışmada işe koşulan bir diğer sosyomatematiksel normdur. Bu norm sayesinde her 
bir yapılan işlem basamağının tekrar edilerek anlaşılmayan veya gözden kaçan kısımların öğretmenin rehberliğinde ortadan kalkması sağlanmıştır. Hatta bu süreçte altta yatan matematiksel bilgilerin ortaya çıkarılması da sağlanmıştır. Öğrenme güçlüğüne sahip öğrencilerin en zayıf olduğu alanlardan birisi hafızadır (Van de Walle, Karp ve Bay-Williams, 2014), dolayısıyla yapılan işlemin tekrar öğretmen tarafından açıklanması bu öğrencilerin yapılan işlem adımlarını nedenleri ile açıklaması onların konuyu daha iyi anlamasını sağlanacaktır. Aynı zamanda bu norm müzakere edildiğinde ders ortamında Güven ve Dede (2017) tarafından ortaya çıkarılan her bir çalışma için adımlar ve açıklamalar açık ve detaylı olarak açıklama sosyal normu ile uyuşmaktadır. Bu açıdan bakıldığında Sekiguchi (2005) tarafından belirtildiği gibi sosyomatematiksel normların oluşumda sosyal normların etkili olduğu unutulmamalıdır. Yine alan yazın çalışması incelendiğinde Lopez ve Allal (2007)'1n problem çözme sürecini incelediği bir sınıf ortamında öğretmenin bu normu kullandığı belirtilmiştir.

Çalışmada oluşturulması amaçlanan bir diğer sosyomatematiksel norm ise matematiksel doğruluğu kabul edilen çözümlerin yaptırılması normudur. Yani öğretmen öğrencisinin kabul gören matematiksel çözümüne odaklanmıştır. Bu normun oluşma sürecinde öğrencilerin hem kavramsal hem de işlemsel anlamaları analiz edilmiş olur (Stephan ve Cobb, 2003). Burada önemli olan problem çözerken öğrencilerin işlemsel ve kavramsal anlamalarını ön plana çıkarmaktır. Ayrıca bu süreçte öğrencilerin hem nasıl düşündükleri hem de nasıl bir sonuca ulaştıkları ortaya çıkarılır. Bu bağlamda çalışmada bulmuş olduğumuz bu norm Tatsiz ve Koleza (2008)'nın öğretmen adaylarıyla yaptığı çalışmasında matematiksel geçerlilik normu ile örtüşmektedir. Çalışmada öğretmenler matematiksel olarak doğruluğu kabul edilen çözüme odaklandıkları gibi basit, kolay ve etkili çözümler sergileme yoluna da gitmeye çalışmışlardır. Öğretmen çözüme ilişkin farklı yollar göstererek bunlar içerisinden en basit ve etkili olanını öğrenme güçlüğüne sahip öğrencisine sunmuştur. Sınıfta yapılan farklı çözümlerde bir çözümün farklı olup olmadığı tartışılırken aynı zamanda çözümlerin basit, kolay veya etkili olduğu da ortaya konulur. McClain ve Cobb (2001)'a göre bu norm farklı bir matematiksel çözümün müzakere edilmesinin bir sonucu olarak ortaya çıkmaktadır. Bu norm için öğretmenin öğrencisinin sorunun cevabı üzerinde fazla zaman kaybetmesini engellemek istediği ve çözümün en basit yolunu tercih ederek öğrencinin daha rahat anlayabilmesini sağlamaya çalıştığı söylenilebilir. Bu öğrencilere çözümün karmaşık değil de basit yoldan sunulması özellikle hafıza problemi yaşayan öğrenme güçlüğüne sahip öğrenciler için oldukça etkili bir yöntemdir denilebilir. Ancak Lopez ve Allal (2007) kaynaştırma olmayan bir sınıf ortamında gerçekleştirdiği çalışmasında bu normu ortaya çıkarabilecek bir sınıf ortamının oluşturulmasının zor bir süreç olduğunu belirtmiştir. Fakat matematik yaparken öğrencilerin ihtiyaçlarına karşılık veren bir sınıf ortamının gerekliliğinin de tartışılmaz olduğu söylenebilir.

Rehberlik ederek doğruyu buldurma sosyomatematiksel normu çalışmada işe koşulan bir diğer normdur. MEB (2018)'e göre öğretmenlerin görevi, öğrenme ve öğretme sürecini yönlendiren; araştıran, sorgulayan, öğrencilerin gelişmelerine yardım eden bir rehber olarak belirtilmiştir. Nitekim çalışmada kaynaştırma öğretmeninin rehber rolünü üstlenerek öğrenci merkezli bir sinıf ortamında öğrenmenin yapılandırılma sürecine katkı sağladığı görülmüştür. Esasında bu norm 
öğretmenin akademik ve teknik açıdan yardım etmesi şeklinde sosyal normunun sonucunda ortaya çıkmıştır. Öyle ki, Partanen ve Kaasila (2015) yaptıkları çalışmada matematiksel nesnelerin özelliklerine dayanan sosyomatematiksel normların oluşturulma sürecinde sosyal normların etkili olduğunu belirtmişlerdir.

Eisenhart (1988)'in dediği gibi, toplumun matematiksel anlam ve uygulamalarına ilişkin matematiksel öğrenme hem bireysel inşaat süreci hem de kültürleşme süreci olarak görülebilir. Bu bağlamda sınıf mikro kültürü içerisindeki öğretmen ve öğrenci etkileşimi son derece önemlidir. Bunun sonucu olarak sınıf mikro kültürü içerisinde sosyomatematiksel normların oluşturulması matematik eğitiminin kalitesinin artırılmasına katkıda bulunabilir (Song ve Yim, 2007). Aynı zamanda sosyomatematiksel normlar, matematik dersinde öğretme ve öğrenme etkinliklerinin kalitesini belirlerken, öğrencilerin matematiksel etkinliklerini yönlendirir ve teşvik eder. Daha önceki yapılan çalışmalarda da sosyomatematiksel normlar, temel olarak öğrencilerin sinıfta oluşturulan kavramsal öğrenmelerin detaylı analizine öncül olarak gösterme eğilimindedir. Sosyomatematiksel normların inşa edilmesinde bir sinıf topluluğunun sosyal yapısından ziyade, bir sınıf topluluğunda kurulan matematiksel mikro kültürün özünü yakalaması amaçlanmaktadır (Yackel ve Cobb, 1996). Her sınıfın kendi içerisinde sosyomatematiksel etkileşim normları vardır. Bu bağlamda bir sınıf mikro kültüründe sosyomatematiksel normlar otomatik olarak oluşmaz, öğretmen- öğrenci, öğrenci-öğrenci etkileşimi ile matematiksel fikirlerini ifade ederken veya paylaşırken oluşur. Bu çalışmada ise işe koşulan normların çoğunlukla norm olmaya aday normlar oldukları görülmüştür. Bu denli avantajı olan sosyomatematiksel normların öğrenme ortamında kullanılması anlamlı öğrenmenin sağlanılması, olumlu sınıf ikliminin oluşması açısından özellikle kaynaştırma öğrencileri için avantaj olabilir. Dolayısıyla çalışmadaki norm adaylarının sınıf mikrokültürü içerisinde sıklıkla tekrar edilmesi ile ilgili davranışların norma dönüşmesi ve tüm sınıfça benimsenmesi sağlanılabilir. $\mathrm{Bu}$ anlamda kaynaştırma öğretmenlerinin sınıf ortamlarını sosyomatematiksel normları daha fazla dikkate alarak düzenlemesi önerilebilir.

\section{Kaynakça}

Akyol, H. (1997). Öğrenme güçlüğü olan çocuklara okuma yazma öğretimi. Milli Eğitim.

Akyüz, D. (2014). Çember özelliklerini öğretmeyi amaçlayan teknoloji ve sorgulama tabanlı bir sınıfta oluşan sosyomatematiksel normların incelenmesi. Eğitim ve Bilim, 39(175) . doi: http:/ / dx.doi.org/10.15390/EB.2014.3220

Boyunduruk, S. (2014). Sınıfta sosyal normların geliştirilmesinde materyal kullanımı (Yayımlanmamış Yüksek Lisans Tezi). Gaziantep Üniversitesi, Gaziantep.

Cho, J. (2001). Ethnography for research of mathematics teacher's belief and classroom norm. Journal of Korea Society of Mathematics Education Series E: Communications of Mathematical Education, 12, 349-361.

Clark, P. G., Moore, K. C., and Carlson, M. P. (2008). Documenting the emergence of speaking with meaning as a sociomathematical norms in professional learning community discourse. Journal of Mathematical Behaviour, 27(4), 297-310. https:// doi.org/10.1016/j.jmathb.2009.01.001 
Cobb, P. (1999). Individual and collective mathematical development: The case of statistical data analysis. Mathematical Thinking and Learning, 1(1), 5-43. https://doi.org/10.1207/s15327833mt10101_1

Cobb, P. (2000). Conducting teaching experiments in collaboration with teachers. In A. E. Kelly and R. A. Lesh (Eds.), Research design in mathematics and science education (pp. 307-333). Mahwah, NJ: Lawrence Erlbaum.

Cobb, P., Gravemeijer, K., Yackel, E., McClain, K., and Whitenack, J. (1997). Mathematising and symbolising: the emergence of chains of signification in one first-grade classroom. Situated cognition theory: social, semiotic and neurological perspectives NJ: Lawrence Erlbaum.

Cobb, P. and Yackel, E. (1996). Constructivist, emergent, and sociocultural perspectives in the context ofdevelopmental research. Educational Psychologist, 31(3),175-190.

Cobb, P., and Whitenack, J. W. (1996). A method for conducting longitudinal analyses of classroom videorecordings and transcripts. Educational Studies in Mathematics, 30(3), 213-228. https:// doi.org/10.1007/BF00304566

Cobb, P. and Bauersfeld, H. (1995). The emergence of mathematical meaning: Interaction in classroom cultures. Psychology Press.

Cobb, P., Yackel, E., and Wood, T. (1992). Interaction and learning in mathematics Classoom situations. Educational Studies in Mathematics, 23(1), 99-122. https:/ / doi.org/10.1007/BF00302315

Eisenhart, M. A. (1988). The ethnographic research tradition and mathematics education research. Journal for Research in Mathematics Education, 19(2), 99-114.

Fusch, D., Mock, D., Morgan, P. L., and Young, C. L (2003). Responsiveness-toIntervention: Definitions, Evidence, and Implications for the Learning Disabilities Construct. Learning Disabilities Research and Practice, 18(3), 157-171. https:/ / doi.org/10.1111/1540-5826.00072

Gülburnu, M. (2019). Problem çözümlerinin tartışıldı̆̆ı öğrenme ortamında sosyomatematiksel normların ve öğrenme firsatlarının incelenmesi. (Yayımlanmamış Doktora Tezi). Adıyaman Üniversitesi. Adıyaman.

Güven, N. D., and Dede, Y. (2017). Examining social and sociomathematical norms in different classroom microcultures: mathematics teacher education perspective. Educational Sciences: Theory and Practice, 17(1), 265-292.

Kang, S. M., and Kim, M. K. (2016). Sociomathematical norms and the teacher's mathematical belief: A case study from a Korean in-service elementary teacher. Eurasia Journal of Mathematics, Science and Technology Education, 12(10), 2733-2751. https:/ / doi.org/10.12973/ eurasia.2016.1308a

Kazemi, E. (2008). School development as a means of improving mathematics teaching and learning: Towards multidirectional analyses of learning across contexts. In The Handbook of Mathematics Teacher Education: Volume 3 (pp. 207-230). Brill Sense. https://doi.org/10.1163/9789087905491_011

Lampert, M. (1990). When the problem is not the question and the solution is not the answer: Mathematical knowing and teaching. American Educational Research Journal, 27(1), 29-63. https:/ / doi.org/10.3102/00028312027001029 
Levenson, E., Tirosh, D., and Tsamir, P. (2009). Students' perceived sociomathematical norms: The missing paradigm. The Journal of Mathematical Behavior, 28(2-3), 171-187. https://doi.org/10.1016/j.jmathb.2009.09.001

Lopez, L. M. and Allal, L. (2007). Sociomathematical norms and the regulation of problem solving in classroom microcultures. International Journal of Educational Research, 46, 252-265. https:/ / doi.org/10.1016/j.ijer.2007.10.005

McClain, K. \& Cobb, P. (2001). An analysis of development of sociomathematical norms in one first-grade classroom. Journal for Research in Mathematics Education, 32(3), 236-266. https://doi.org/10.2307/749827

Milli Eğitim Bakanlı̆̆1 (MEB) (2018). Matematik dersi öğretim programı: İlkokul ve Ortaokul 1-8. siniflar. Ankara.

Özkubat, U., ve Özmen, E. R. (2017). Öğrenme güçlüğü olan öğrencilerin matematik problemi çözme süreçlerinin incelenmesi: sesli düşünme protokolü uygulamas1. Ankara Üniversitesi Eğitim Bilimleri Fakültesi Özel Ĕ̆itim Dergisi, 19(1), 155-180. https:/ / doi.org/10.21565/ozelegitimdergisi.299494

Özmantar, M. F., Bingölbali, E., Demir, S., Sağlam, Y., ve Keser, Z. (2009). Değişen öğretim programları ve sınıf içi normlar. Uluslararası İnsan Bilimler Dergisi, 6 (2), 1-23.

Partanen, A. M., and Kaasila, R. (2015). Sociomathematical norms negotiated in the discussions of two small groups investigating calculus. International Journal of Science and Mathematics Education, 13(4), 927-946. https:/ / doi.org/10.1007/ s10763-014-9521-5

Sánchez, V., \& García, M. (2014). Sociomathematical and mathematical norms related to definition in pre-service primary teachers' discourse. Educational Studies in Mathematics, 85(2), 305-320. https:/ / doi.org/10.1007/ s10649-013-9516-0

Sart, H., Ala, H., Yazlık, Ö., and Yılmaz, F. (2004, July). Where is Turkey in inclusive education. In Recommendations for Educationalists. Report presented at the 123th National Educational Sciences Congress, Malatya.Sfard, A. (2008). Thinking as communicating: Human development, the growth of discourses, and mathematizing. Cambridge University Press.

Shin, M., and Bryant, D. P. (2015). A synthesis of mathematical and cognitive performances of students with mathematics learning disabilities. Journal of Learning Disabilities, 48(1), 96-112. https:/ / doi.org/10.1177/0022219413508324

Song, K. H., and Yim, J. H. (2007). Establishing the culture of elementary mathematics classroom focused on the precise use of mathematical language. School Mathematics, 9(2), 181-196.

Stephan, M., and Cobb, P. (2003). The methodological approach to classroom-based research. Journal for Research in Mathematics Education. Monograph, 12, 36-50.

Sucuoğlu, B., ve Kargın, T. (2008). Ilköğretimde kaynaştırma uygulamaları yaklaşımlar, yöntemler, teknikler. İstanbul: Morpa Yayınları.

Swanson, H. L., and Jerman, O. (2006). Math Disabilities: A Selective Meta-Analysis of the Literature. Review of Educational Research, 76(2), 249-274.

https:// doi.org/10.3102/00346543076002249

Şay, R. (2014). Matematik öğretmen adaylarının teknoloji destekli öğretim süreçlerinin sosyokültürel yaklaşımla incelenmesi (Yayımlanmamış Yüksek Lisans Tezi). Marmara Üniversitesi, İstanbul. 
Şenel, H. G. (1995). “Özel öğrenme güçlüğü" terimi yerine alternatif arayışlar. Ankara Üniversitesi Ĕ̆itim Bilimleri Fakültesi Özel Eğitim Dergisi, 2(1),40-46. https://doi.org/10.1501/Ozlegt_0000000022

Tatsis, K., and Koleza, E. (2008). Social and socio-mathematical norms in collaborative problem-solving. European Journal of Teacher Education, 31(1) ,89100. https:/ / doi.org/10.1080/02619760701845057

Thompson, A. G. (1984). The relationship of teachers' conceptions of mathematics and mathematics teaching to instructional practice. Educational Studies in Mathematics, 15(2), 105-127. https:/ / doi.org/10.1007/BF00305892

Trouche, L. (2004). Managing complexity of human/machine interactions in computerized learning environments: Guiding students' command process through instrumental orchestrations. International Journal of Computers for Mathematical Learning, 9, 281-307. https:// doi.org/10.1007/s10758-004-3468-5

Toluk-Uçar, Z. (2016). Sosyomatematiksel normlar. E. Bingölbali, S. Arslan ve İ. Ö Zembat (Ed.), Matematik eğitiminde teoriler içinde (s. 605-627). Ankara: Pegem Akademi.

Van de Walle, J., Karp, K.S., and Bay-Williams, J.M. (2013). Elemantry and Middle School Mathematics Teaching developmentally. Ankara: Nobel akademi.

Van Zoest, L. R., Stockero, S. L., and Taylor, C. E. (2012). The durability of proffesional and sociomathematical norms intentionally fostered in an early pedagogy course. Journal of Mathematics Teacher Education, 15(4) , 293-315. https://doi.org/10.1007/s10857-011-9183-y

Yackel, E. (2001). Explanation, justification and argumentation in mathematics classroms. InM. van den Heuvel-Panhuizen (Ed.), Proceedings of the 25th Conference of the International Group for the Psychology of Mathematics Education, Vol. 1 (pp. 9-24). Utrecht, The Netherlands: Freudenthal Institute.

Yackel, E., Rasmussen, C., and King, K. (2000). Social and sociomathematical norms in an advanced undergraduate mathematics course. The Journal of Mathematical Behavior, 19(3), 275-287. https:/ / doi.org/10.1016/S0732-3123(00)00051-1

Yackel, E., and Cobb, P. (1996). Sociomathematical norms, argumentation, and autonomy in mathematics. Journal for Research in Mathematics Education, 27(4), 458-477. https:/ / doi.org/10.2307/749877

Yıldırım, A. ve Şimşek, H. (2005). Sosyal bilimlerde nitel araştırma yöntemleri. Ankara: Seçkin Yayınevi.

\section{Summary}

\section{Introduction}

While analyzing mathematics learning, scientists made use of some concepts such as classroom microculture, and defined classroom microculture as the cognitive structures of class members (teachers and students) and the common behaviors resulting from the mutual interaction of class members in the learning and teaching process. As a part of classroom microculture, Yackel and Cobb used the norm word to refer to all of the unwritten common understandings and classroom rules that govern the mutual expectations, rules and behaviors that arise between teachers and students. Norms are classroom rules or common understandings that continue in the form of an unwritten regular pattern that teachers create or contribute to the 
formation of verbally or using body language. From here, it can be said that norms are a set of unwritten rules that govern the interaction between teachers and students in a situation, but are accepted by each individual and require repetition. Norms such as making explanations in social norms, understanding the solution aspects of their peers and making justifications led to the formation of the concept of sociomathematical norm. In the classroom microculture, what the students aim to learn in mathematics, which mathematical explanations they accepts as correct and how they makes sense to do mathematics are discussed within socio-mathematical norms. Sociomathematical norms are closely related to social norms and determine the quality of teaching and learning activities in a mathematics classroom, and also guide students' mathematical activities and encourage them to learn. Cobb and Yackel considered sociomathematical norms as the normative aspects of all classroom discussions specific to students' mathematical activities. The teacher shows what is acceptable and thus creates the sociomathematics norms she/he wants to establish in his classroom. The teacher is one of the most important factors in structuring students' learning in a better system. Therefore, it can be said that all the responses given by the teachers, including the gestures and gestures used by the teachers in the classroom environment, are important for the students. According to the modern understanding of education, helping and guiding the student in the learning process is among the teacher's duties, and MEB warns teachers that all students should be treated equally in their approach. As a matter of fact, there are also students with learning difficulties among these students. In the literature, the special learning disability is defined as an unexpected, non-typical learning failure where the cause of the problem is not clear. Studies have shown that these students have lower cognitive levels than their peers with normal development. Considering these differences, the arrangement of the classroom environment to include all individuals is closely related to the attitude of the teacher. In this study, it was aimed to examine the sociomathematical norms that mathematics teachers who have students with learning disabilities in the inclusive class try to create in the classroom environment.

\section{Method}

The case study method, one of the qualitative research methods, was used as a design in the study. The study was actualized in spring semester 2019-2020 academic year, a province in western Turkey. The participants of study were three math teachers of 5th grader students. Document analysis and observation form were used to collect data in the study. The data were collected using visual and audio video recording and observation form. In the study, it was deemed appropriate to consider fractions and gains related to operations with fractions. Two cameras were used in the study, the first camera was used to monitor the learning disability student and teacher, and the second camera was used to monitor the other students in the class. Each teacher was observed 18 hours. The data obtained with the video recordings of the students and the notes of the observer were analyzed using content analysis. As a result of the content analysis of the data, each norm that could be a sociomathematical norm was determined. In order to become a norm, a behavior must be repeated at least three times for this study. 


\section{Findings and Results}

In the study, it was determined that there were candidate norms that teachers generally tried to establish norms in their classrooms. It was determined that only showing different solutions in mathematical sense and accepting mathematical explanation without justification were norm, while others were candidates for norm. In fact these behaviors could be repeated frequently if the students were given the appropriate environment and necessary time. For example, Emin teacher asked the mainstreaming student for his explanation at the beginning of his lesson, but the student did not respond. In here, because of the disadvantages such as the student with learning disability not wanting to talk too much, remaining recessive, and being distracted quickly, the teacher requesting justification behavior may not be maintained. Therefore, it can be said that while behavior may be the norm, it remains a candidate for the norm. In general, it can be said that due to such reasons, some of the norms that teachers try to establish in their classrooms remain as norm candidates for teachers.

\section{Araştırmanın Etik İzinleri}

Yapılan bu çalışmada "Yükseköğretim Kurumları Bilimsel Araştırma ve Yayın Etiği Yönergesi" kapsamında uyulması belirtilen tüm kurallara uyulmuştur. Yönergenin ikinci bölümü olan “Bilimsel Araştırma ve Yayın Etiğine Aykırı Eylemler” başlığı altında belirtilen eylemlerden hiçbiri gerçekleştirilmemiştir.

Etik kurul izin bilgileri

Etik değerlendirmeyi yapan kurul adı $=$ Uşak Üniversitesi Sosyal ve Beşeri Bilimler Bilimsel Araştırma ve Yayın Etiği Kurulu

Etik değerlendirme kararının tarihi=13.02.2020

Etik değerlendirme belgesi sayı numarası= 89784354-050.99-

\section{Authors' Biodata/ Yazar Bilgileri}

Hava ÖKSÜZ Ortaokulda matematik öğretmenliği yapmakta ve matematik eğitimi alanında yüksek lisans öğrencisidir. Yüksek lisans tezini öğrenme güçlüğüne sahip öğrencilerin matematik öğretmenlerinin sosyomatematiksel normları üzerine yazmaktadır.

Hava Oksuz works mathematics in a secondary school and is a graduate student in mathematics education. She writes her master's thesis on the sociomathematical norms of mathematics teachers of learning disabilities students.

Nejla GÜREFE Uşak Üniversitesi Eğitim Fakültesi'nde doçent olarak görev yapmaktadır. Matematik Eğitimi alanında akademik çalışmalar yapmaktadır. Çalışma alanları arasında geometri öğretimi, kavram öğretimi, kaynaştırma eğitimi yer almaktadir.

Nejla Gurefe works as a associate professor in Usak University Faculty of Education. She conducts academic studies in the field of Mathematics Education. Her fields of study include geometry education, teaching of concept and inclusive education. 